\title{
Comparative Study On Nursing Of Different Strains Of Tilapia (Oreochromis niloticus) In Bangladesh
}

\author{
Hossain MA*, Islam MJ, Uddin MM, Hossain MM and Kunda M \\ Department of Aquatic Resource Management, Faculty of Fisheries; Sylhet Agricultural University, Bangladesh
}

[Received: December 17, 2015; Accepted: December 28, 2015]

\begin{abstract}
This study was conducted to investigate and compare the growth performance of four Tilapia strains in hapa nursing with the aim to find out the best strain of tilapia. The research was conducted by four treatments with five replicates each. The tilapia fry were collected from, BFRI source from BFRI HQ, Mymensingh stocked in Treatment-1; unknown source from Hi-Tech Tilapia Hatchery Dagoanbhuiya, Feni in Treatment-2, Philipine strain from Green Field Tilapia Hatchery, Laxmipur in Treatment-3 and fry from Breeding Cohort, Sonar Bangla Hatchery, Bamna, Barguna in Treatment-4. The Individual stocking weight $(\mathrm{g})$ of fry was average $0.01 \mathrm{~g}$. The fries were stocked in 12 hapa at same stocking density of $1200 \mathrm{fish} / \mathrm{m}^{2}$. Each of the hapa was $2 \mathrm{~m} \times 1 \mathrm{~m} \times 1 \mathrm{~m}$ size and fixed in an earthen ponds. Supplementary feed with $31.29 \%$ of protein level consisting of rice bran $(25 \%)$, mustard oil cake $(15 \%)$, wheat flour $(30 \%)$ and fish meal $(30 \%)$ was given at the rate of $40 \%$ of their body weight per day manually, four times a day at the beginning of the experimental period and reduced to $25 \%$ of their body weight and continued up to harvesting period. The results showed that fry of Treatment-4 strain was the best strain and had significantly $(\mathrm{p}<0.05)$ higher final mean body weight $(\mathrm{FMBW})$, mean body weight gain (MBWG), specific growth rate (SGR) $(9.75 \%)$, gross yield (GY) (2.13) and Net yield (NY) (2.12) than the Treatment-1, Treatment-2 strains and Treatemnt-3 strain. Treatment-4 strain had the fastest growth rate, whereas the lowest performing strain was that from Treatment- 2 . We also analyzed survival rate of the fish from stocking to harvest, survival rate was highest in Treatment-4 strain $(80 \%)$ where lowest is Treatment-3. Treatment-4 stain also showed the best feed conversion ratio (FCR) 1.62 than others. Considering the overall performance it can be concluded that tilapia strain collected from Breeding Cohort source is best among the four strains. However, further research may still be needed to compare more strains from different water body to evaluate the genetic potential for Tilapia.
\end{abstract}

Keywords: Comparative study on nursing on Strains of Tilapia.

\section{INTRODUCTION}

Fisheries play a vital role in the socio-economic development, fulfilling the animal protein and micronutrient demand, creating employment opportunity, alleviating poverty and earning foreign exchange for the country. There are more than 1.2 million people are directly employed in the fisheries sector and another 12 million people indirectly involved in this sector for their livelihood. The contribution of fisheries sector in the GDP of Bangladesh is increasing day by day. The contribution of fisheries in the GDP of Bangladesh is $4.39 \%$ but it contributes substantially to the national income through export earnings. In the recent year 2011-2012, approximately 0.92 lakh metric tons fishery product exported and the price in TK 4,704 crore, the total fish production is estimated at 32.62 lakh metric tons of which share of marine sector is 5.87 lakh $\mathrm{m}$. tons and inland contribution is 26.75 lakh Mt.

The name, "Tilapia" was derived from an African Bushman word simply meaning fish. Fishes belonging to the family Cichlidae is referred to as Tilapias [32]. There are about 100 species; most of them are native to Western African Rivers [5]. Of these, only Tilapia (Tilapia zillii and T. rendak) and Oreochromis (0. niloticus, O. mossambicus and $O$. aureus) species are in widespread use [22]. Due to their small size and slow growth rate, $T$. zillii and $T$. rendali are rarely cultured but are often used to control weeds in irrigation canals, mostly in some African and Latin American countries. Among Oreochromis species O. aureus is familiar for its tolerance to saline and cold water conditions. Despite the introduction after 1950 to several Asian countries O. mossambicus did not flourish and proved to be a pest, because of their ability to mature early and breed more frequently, resulting in over population in ponds. As a result the species considered as nuisance fish by producers and consumers in the tropics [21].

In the view of cultured fish species, tilapia is one of the most commercially important and widely used fish in the global aquaculture production particularly in tropical and subtropical areas [19]. Oreochromis niloticus is by far the most important tilapia species and distributed throughout the world [26]. The importance of Oreochromis niloticus seams from its biological reasons: fast growth, high food conversion ratio, readily accepting artificial feeds, ease of breeding in captivity, disease resistance, high fecundity; social reasons: good table food quality, good market price; and acceptable physical appearance: tolerant to a wide range of environmental conditions [6]. Therefore, determination of different factors such as feed quality, stocking density and strain variations for cultured tilapia is essential to maximize its production, profitability and sustainability. Among these, selection of the best strains for efficient 
breeding program is crucial; not only to reach the production goal but also to reduce production cost, to improve disease resistance, utilization of feed resources and product quality [19].

Tilapia are widely recognized as one of the most important fish species for farming in a wide range of aquaculture systems from single small scale waste fed fish ponds to intensive culture systems [27]. They form the mainstay for many poor fish farmers. Annual production exceeds 50,000 Mt in several Asian countries [30]. The main tilapia producing countries are China, Indonesia, the Philippines, Srilanka, Thailand \& Vietnam. Interest in tilapia culture is also increasing elsewhere in the Indian subcontinent and Pacific region countries.

Tilapia has been dubbed the "aquatic Chicken" [23]. Among the wide variety of cultured tilapias, the most widely farmed stock is the Nile tilapia (Oreochromis niloticus). The introduction of tilapia in Bangladesh was first initiated in 1954 with $O$. mossambicus (Peters) from Thailand (Ahmed, 1956) [3]. But their introductions to freshwater ponds soon become unpopular to fish farmers due to some bad characteristics. Later in 1974, high yielding species of tilapia ( 0 . niloticus) was introduced by UNICEF [28] also from Thailand with a hope that it would make a significant contribution to protein supplement for the malnourished multitudes. The attempt was not successful because of very little efforts were made to understand its biology and adaptive research and the culture management by the farmers. Fisheries Research Institute again brought a fresh batch of nilotica from Thailand in 1987. With this batch, the institute at its Freshwater Station at Mymensingh and NGQ's to hundreds of farmers throughout the country.

In order to achieve the objectives of the study experiment was conducted by hapa nursing in $\mathrm{Hi}$ Tech Tilapia Hatchery at Dagonbhuiya of Feni district. The entire people associated with the research received training on hapa and cage nursing of tilapia and how to make hapa and cages. Cage materials were purchased from Fini district town. At the end of the research fingerling were sold to one grow-out farmer directly and some of the fingerling sold through fry trader. The farmers kept some of the fry in the cages for grow-out farming. Thus tilapia fingerling production, distribution and grow-out farming system and its input and product marketing chain has been developed in the Feni region of Bangladesh.

The research was carried out in the pond of Hi-Tech Tilapia Hatchery, Dagon Bhuiya upazila of Feni district to achieve the following objectives: to find out the best strain of tilapia fry those are using as brood in the tilapia hatcheries in Bangladesh and to introduce tilapia fingerling production system using hapa and cages in the Noakhali region of Bangladesh.

\section{MATERIALS AND METHODS}

Methodology is an indispensible part of any researchers. The methods of data collection depend upon nature, aims and objectives of the research undertaken. There were several methods of collection of data and information. Among those methods selection of a particular method depends on many considerations. The research methodologies of

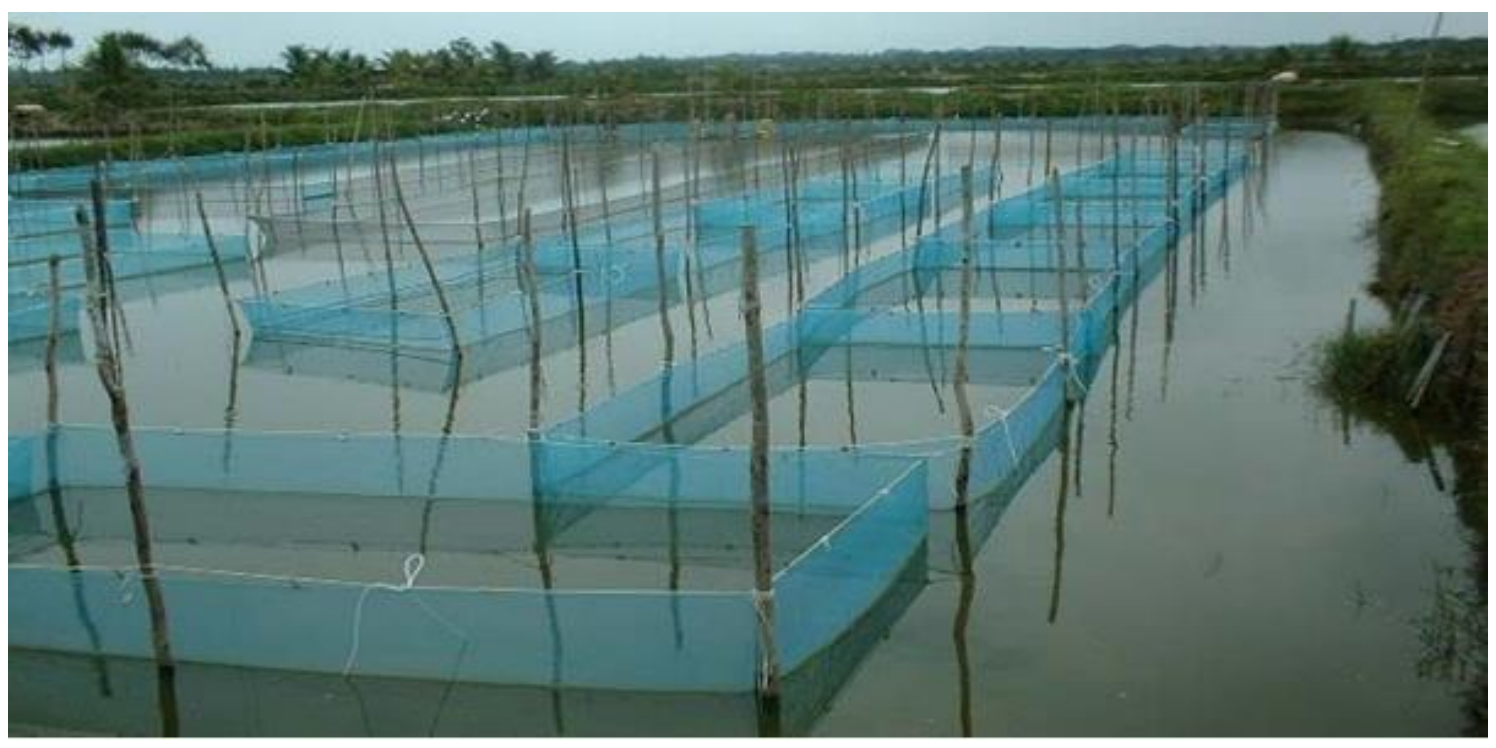

Figure 1: Nursing of Fry in Hapa

initiated on-station and on-farm research and developed low input and low cost technologies. Such technologies, meanwhile, have been transferred through Government extension workers the present study are described below:

\section{Research site}

The research was carried out in Hi Tech Tilapia Hatchery at Dagonbhuiya of Feni district. Feni 
district (Chittagong division) area $928.34 \mathrm{sq} \mathrm{km}$, located in between $22^{\circ} 44^{\prime}$ and $23^{\circ} 17^{\prime}$ north latitudes and in between $91^{\circ} 15^{\prime}$ and $91^{\circ} 35^{\prime}$ east longitudes. It is bounded by Comilla district and Tripura state of India on the north, Noakhali and Chittagong districts on the south, Tripura state of India on the east, Noakhali district on the west. The hapas and cages were set up in a pond within the Hi Tech Tilapia Hatchery Complex.

\section{Research design}

Hapa were made by fine meshed synthetic net. All the hapas were same in size with $2 \mathrm{~m}$ length, $1 \mathrm{~m}$ width and $1 \mathrm{~m}$ height. The hapas were fixed with bamboo pole and tied up with rope both upper and lower end of the hapa. Hapas were set up one week prior to stocking of tilapia fry.

\section{Stocking of fry}

All the tilapia fry were stocked in a same day. During transportation the fry were packed in plastic bag with water and oxygen. The fry were transported

Table 1: Formulation of feed gm/100 gm dry feed)

\begin{tabular}{lc}
\hline Ingredients & Feed \\
\hline Fish meal & 30.00 \\
Mustard oil cake & 15.00 \\
Rice bran & 25.00 \\
Wheat flour & 30.00 \\
\hline & 100.00 \\
\hline Protein $(\%)$ & 31.29 \\
\hline
\end{tabular}

Table 2: Proximate composition of feed ingredients (\% of dry matter basis)

\begin{tabular}{|c|c|c|c|c|c|c|}
\hline \multirow[t]{2}{*}{ Ingredients } & \multicolumn{6}{|c|}{ Components } \\
\hline & $\begin{array}{c}\text { Dry } \\
\text { matter }\end{array}$ & $\begin{array}{l}\text { Crude } \\
\text { protein }\end{array}$ & $\begin{array}{l}\text { Crude } \\
\text { lipid }\end{array}$ & $\begin{array}{l}\text { Crude } \\
\text { fibre }\end{array}$ & Ash & $\mathrm{NFE}$ \\
\hline Fish meal & 86.85 & 59.61 & 11.22 & 2.67 & 22.76 & 3.74 \\
\hline $\begin{array}{l}\text { Mustard oil } \\
\text { cake }\end{array}$ & 85.54 & 30.33 & 13.44 & 12.12 & 9.73 & 34.38 \\
\hline Rice bran & 89.47 & 11.74 & 9.23 & 18.60 & 16.40 & 41.04 \\
\hline Wheat flour & 89.73 & 19.73 & 0.38 & 0.00 & 0.40 & 79.49 \\
\hline
\end{tabular}

Table 3: Physico-chemical characteristics of pond water during study period

\begin{tabular}{lcccc}
\hline \multicolumn{1}{c}{ Parameters } & April & May & June & July \\
\hline Water temperature $\left({ }^{\circ} \mathrm{C}\right)$ & 25.67 & 26.75 & 28.06 & 30.05 \\
Dissolved oxygen $(\mathrm{mg} / \mathrm{l})$ & 4.05 & 5.84 & 5.97 & 5.75 \\
$\mathrm{pH}$ & 7.90 & 7.87 & 8.01 & 8.10 \\
\hline
\end{tabular}

Swim-up fry (7-8 days old) of tilapia were used for hapa nursing and grown up to $4-5 \mathrm{~g}$ size. Each of the hapa was $2 \mathrm{~m} \times 1 \mathrm{~m} \times 1 \mathrm{~m}$ size. The research was conducted by four treatments with five replicates each. The tilapia fry were collected from, BFRI source from BFRI HQ, Mymensingh stocked in Treatment-1 and unknown source from $\mathrm{Hi}-\mathrm{Tech}$ Tilapia Hatchery Dagoanbhuiya, Feni stocked in Treatment-2, Philippine strain from Green Field Tilapia Hatchery, Laxmipur stocked in Treatment-3 and fry from Breeding Cohort, Sonar Bangla Hatchery, Bamna, Barguna stocked in Treatment-4. Stocking density were same in all the treatments at the rate of $600 / \mathrm{m}^{3}$.

\section{Site Selection for placement of hapa}

Large bodies of water tend to be better suited for hapa nursing and cage culture than small ponds because the water quality is generally more stable and affected less by fish waste. Exceptions are eutrophic water rich in nutrients and organic matter. Small (1 to 5 acre) ponds can be used for hapa culture, but provisions for water exchange or emergency aeration may be required. Hapas should be placed where water currents are greatest, usually to the windward side.

Hapa making and set-up by pick-up van and stocked early in the morning. Before stocking the fry, plastic bags were kept for half an hour inside the hapa to minimize the water temperature as hapa. The initial weight of fry in Treatment-1, Treatment-2, Treatment-3 and Treatment-4 was $0.018,0.019,0.01$ and $0.01 \mathrm{gm}$, respectively. The stocking density of fry in all hapas was $1200 / \mathrm{m}^{3}$.

\section{Feeding}

Feeding was started with commercial nursery feed at $50 \%$ body weight (bw) of fish initially and gradually reduced up to $6 \%$ bw. The feed consist of rice bran $25 \%$, wheat flour $30 \%$, mustard oil cake $15 \%$ and fish meal $30 \%$.

Feed were spread over the hapa. One third of the feed in the morning 8.00-9.00 hrs, one third during 12.00-13.00 hrs and rest of the feed 16.00-17.00 hrs. Feeding rate were adjusted depending on the requirement of feed according to the body weight of fish sampled every fortnightly.

\section{Sampling of fish and measuring of growth parameters}

50 fishes were sampled every two weeks for their body weight and body length measurement. Length and weight of the fish were measured using ruler and 
digital weight balance (Ohaus portable balance), respectively. Mortality of the fish was also registered throughout the experimental period.

Water quality parameters and weight of 50 individuals will be measured and recorded from each of the hapa and carried out once in a week. Final measurements were taken after two months of stocking and total number of fingerling

Table 4: Comparisons of means $( \pm \mathrm{SD})$ of yield parameters of tilapia fry in different treatments during 51 days culture period.

\begin{tabular}{lllll}
\hline Parameters & Treatment-I & $\begin{array}{l}\text { Treatment- } \\
\text { II }\end{array}$ & $\begin{array}{l}\text { Treatment- } \\
\text { III }\end{array}$ & $\begin{array}{l}\text { Treatment- } \\
\text { IV }\end{array}$ \\
\hline $\begin{array}{l}\text { Individual stocking weight } \\
(\mathrm{g})\end{array}$ & 0.018 & 0.019 & 0.01 & 0.012 \\
$\begin{array}{l}\text { Individual harvest weight } \\
(\mathrm{g})\end{array}$ & $4.16 \pm 0.42^{\mathrm{a}}$ & $3.95 \pm 0.57^{\mathrm{b}}$ & $4.7 \pm 0.28^{\mathrm{c}}$ & $4.5 \pm 0.43^{\mathrm{c}}$ \\
Survival (\%) & $69.6 \pm 5.8^{\mathrm{a}}$ & $79.8 \pm 10.3^{\mathrm{a}}$ & $69.5 \pm 4.4^{\mathrm{b}}$ & $79.2 \pm 7.6^{\mathrm{c}}$ \\
FCR & $2.44 \pm 0.34^{\mathrm{a}}$ & $2.29 \pm 0.45^{\mathrm{a}}$ & $1.76 \pm 0.21^{\mathrm{b}}$ & $1.62 \pm 0.82^{\mathrm{c}}$ \\
SGR $\left(\%\right.$ bw day $\left.{ }^{-1}\right)$ & $8.89 \pm 0.17^{\mathrm{a}}$ & $8.72 \pm 0.24^{\mathrm{b}}$ & $10.08 \pm 0.1^{\mathrm{c}}$ & $9.75 \pm 0.16^{\mathrm{c}}$ \\
& $1.74 \pm 0.27^{\mathrm{a}}$ & $1.87 \pm 0.18^{\mathrm{a}}$ & $1.96 \pm 0.17^{\mathrm{b}}$ & $2.13 \pm 0.24^{\mathrm{c}}$ \\
Gross yield $\left(\mathrm{kg} \mathrm{m}^{-2}\right)$ & $1.73 \pm 0.29^{\mathrm{a}}$ & $1.86 \pm 0.18^{\mathrm{a}}$ & $1.95 \pm 0.17^{\mathrm{b}}$ & $2.12 \pm 0.24^{\mathrm{c}}$ \\
& & & & \\
\hline
\end{tabular}

Water quality parameters (temperature, $\mathrm{pH}$, dissolved oxygen) were measured every day. Different types of instrument use to measure water quality parameter such as thermometer for water temperature, $\mathrm{p}^{\mathrm{H}}$ meter for water $\mathrm{p}^{\mathrm{H}}$ and DO meter for dissolved oxygen in pond water once in two weeks were counted and recorded.

\section{Statistical analysis}

Statistical analysis was done by using SPSS statistical software version17. ANOVA and DMRT were used to analyze the data.

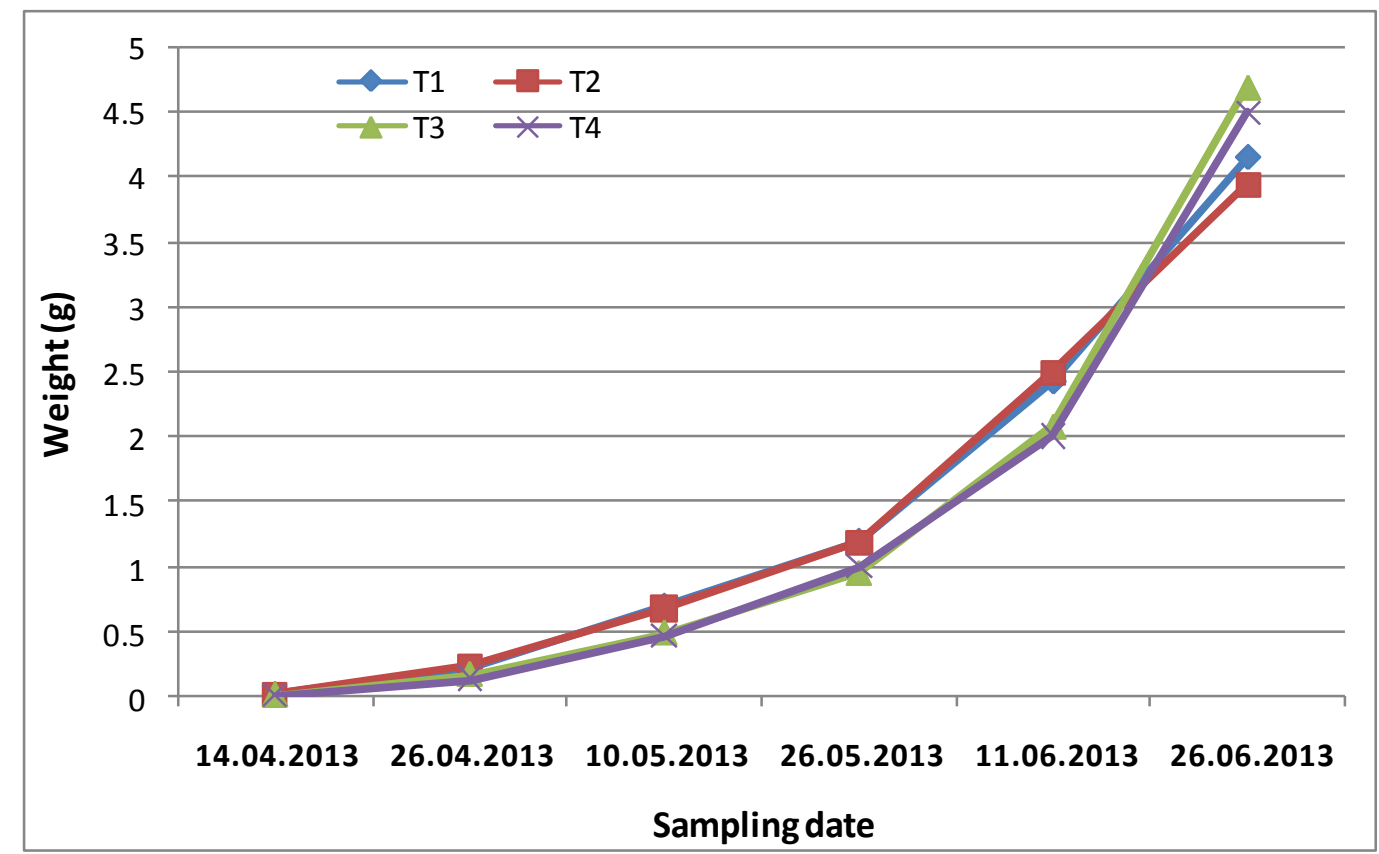

Figure 2: Average cumulative growth of four strain of tilapia in terms of increase in weight (g) over a period of 51 days.

interval with the same instrument.

\section{Monitoring and data collection}

Feeding rate and health condition were checked once in a week. Condition of hapa also checked once in a week whether getting damage or not or excess feed were accumulated at the bottom of the hapa. Length
Benefit cost ratio were calculated based on the local market value of the used inputs and sale value of produced fingerling.

\section{RESULTS AND DISCUSSION}


The present study was investigated on the nursery trial of different strain of tilapia using hapa placed in pond with a view to observe their growth and production performances. The research was carried out in the pond of Hi-Tech Tilapia Hatchery, Dagaon Bhuiya upazila of Feni district to achieve the following objectives such as to find out the best strain of tilapia those are using as brood in the tilapia hatcheries of Bangladesh and introduce tilapia fingerling production system using hapa and cages and provide throughout the country.

The data obtained during sampling and at the end of the research final harvest data were collected and recorded in the computer. The result came out based on the analyzed data are described in below:

The different growth parameters for all the strains mean body weight gain, specific growth rate and daily growth rate as indicator of growth, food conversion ratio as indicator of feed utilization efficiency, gross fish yield as indicator of production potential and length-weight relationships as indicator of growth condition and growth pattern of the fish. The results of the present study revealed that the growth performance of juvenile affected by strain variation and were significantly different $(\mathrm{p}<0.05)$. The Treatment-4 strain showed the highest growth performance while the Treatment-2 strain had the lowest growth performance. The harvesting body weight of the Treatment- 4 strain was nearly $4.7 \mathrm{gm}$ higher than that of the Treatment-1, Treatment-2, and Treatment-3 strains. These results were in line with other work [1], who worked on the growth performance of four different Oreochromis niloticus strains collected from four Egyptian lakes [2].

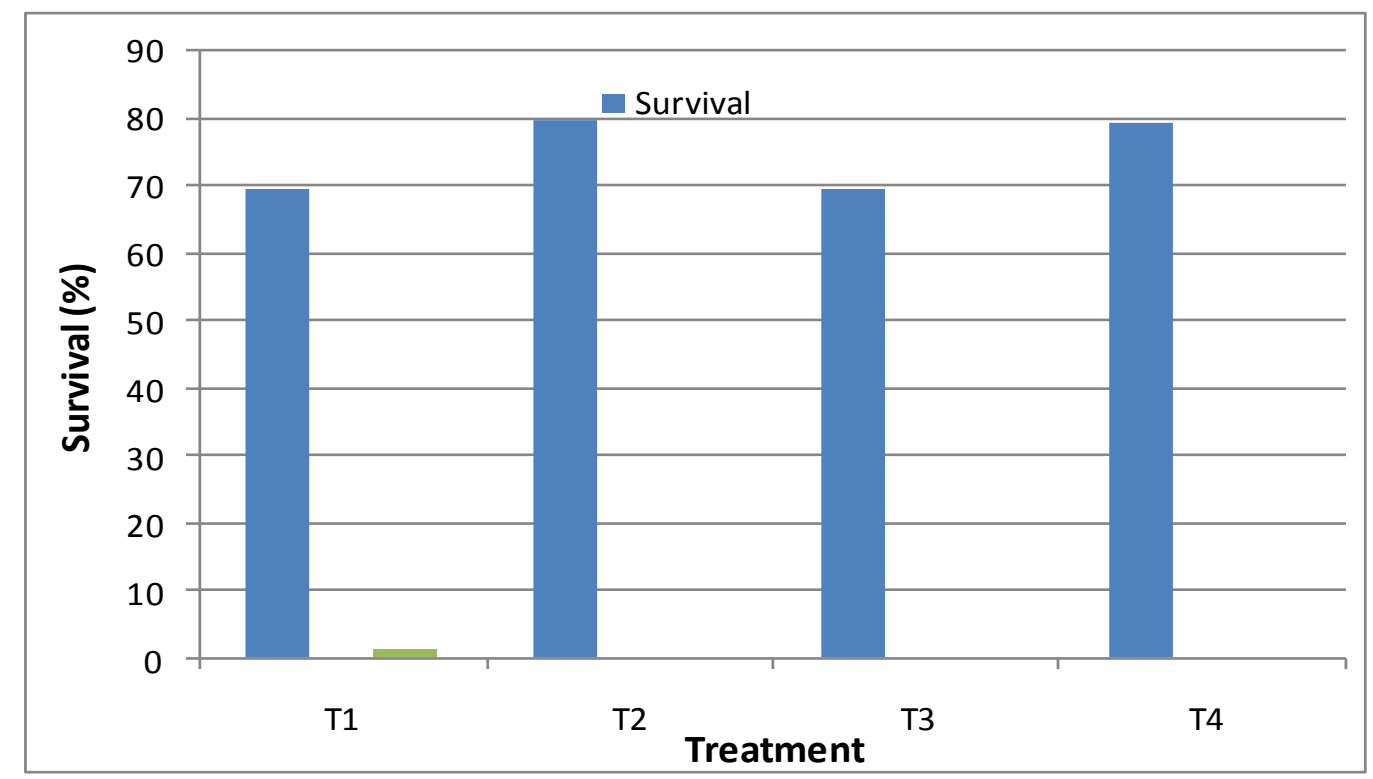

Figure 3: Survival rate of fingerlings of four strain of tilapia over a period of 51 days

were calculated after 51 days of the experiment and were summarized in Table 4. The results revealed that the different growth parameters were significantly $(\mathrm{P}<0.05)$ affected by the strain difference. The highest final mean body weight was observed in the Philipine strain $(4.7 \mathrm{~g})$ followed by Breeding Cohort strain (4.5 g) and unknown source strain $(3.95 \mathrm{~g})$, respectively. Similarly, mean body weight gain and specific growth rate exhibited the same trend.

The growth performance of Tilapia strain depends on genetic materials, food quality, energy content of the food, stocking density and environmental factors. Moreover, the initial mean body size of the fish was homogeneous. Thus, variation in growth performance and food conversion ratio of the fish for all the strains were not affected by external factors and initial body size among the strains. On the other hand, variation in growth performance was caused by strain variation. Thus, in this study comparison of growth performance of different tilapia strains were made based on different growth parameters including
The author reported that growth performance is affected by strain differences. Ridha [29] made a similar observation and reported that growth performance of Oreochromis niloticus is affected by strain differences. The present result is also in agreement with the finding of others $[11,15,25]$ who compared the growth performance of four African and four Asian Oreochromis niloticus strains at different environmental conditions. The authors found that the growth performance of the fish was significantly affected by strain variation in which the African strains had better growth performance than the Asian strains with the exception of Ghanaian strain. Ibrahim et al (2012) also confirmed that growth performance of Oreochromis niloticus is affected by strain variation. The authors reported that Abassa line showed a superior final body weight at harvest $(28 \%)$ over the Kafer El Sheikh strain. Green and Teichert-Coodington [20] also observed that growth of mono-sex and control Nile tilapias, both during treatment and advanced nursing in ponds, was 
similar. Other authors have also reported lack of any differences in growth or survival of mono-sex juvenile fishes compared to controls. Cruz and Ridha [12] observed the performances of Oreochromis spilurus in nursing phase for 68 days in seawater cages. He found no significant differences in mean individual final weight, daily growth rate and survival rate among three stocking densities, but considerable higher yields were
So, considering the FCR Breeding Cohort strain is the best strain out of four used in this study.

The Treatment-4 strain had the highest growth performance with slightly lower feed conversion ratio value than the other strains. This result is in agreement with the work of Abdel-Tawwab [1] who reported that the lowest feed conversion ratio is obtained in the Aswan strain that had the highest growth performance. The feed conversion ratio that

Table 5: Comparisons of economics among different treatment based on $1 \mathrm{~m}^{2}$ area of hapa Currencies are given in Bangladesh Taka, BDT (1 USD = 80 BDT).

\begin{tabular}{|c|c|c|c|c|}
\hline Items & $\begin{array}{l}\text { Treatment- } \\
\text { I }\end{array}$ & Treatment-II & $\begin{array}{c}\text { Treatment- } \\
\text { III }\end{array}$ & $\begin{array}{c}\text { Treatment- } \\
\text { IV }\end{array}$ \\
\hline \multicolumn{5}{|l|}{ Financial inputs } \\
\hline $\begin{array}{l}\text { Hapa cost (Including all cost of } \\
\text { net, rope and bamboo } 2 \mathrm{~m}^{2} \\
\text { hapa cost }=\mathrm{Tk} \text {. 500, it is } \\
\text { considered the hapa can be used } \\
\text { at least four times with in a } \\
\text { season) }\end{array}$ & 62 & 62 & 62 & 62 \\
\hline $\begin{array}{l}\text { Tilapia fry (Tk. } 0.50 \text { per fry) } \\
\text { cost }\end{array}$ & 300 & 300 & 300 & 300 \\
\hline The Food cost & 199 & 202 & 163 & 165 \\
\hline Total costs & 561 & 564 & 525 & 527 \\
\hline \multicolumn{5}{|l|}{ Financial returns } \\
\hline $\begin{array}{l}\text { Total returns (Average Sale } \\
\text { value Tk. } 2.0 \text { per fry) }\end{array}$ & $\begin{array}{c}835 \pm \mathrm{SD} \\
69^{\mathrm{a}}\end{array}$ & $957 \pm \mathrm{SD} 123^{\mathrm{a}}$ & $834 \pm$ SD $53^{\mathrm{a}}$ & $950 \pm \operatorname{SD} 92^{\mathrm{a}}$ \\
\hline Net benefit & $\begin{array}{c}274 \pm \text { SD } \\
62^{\mathrm{a}}\end{array}$ & $393 \pm \mathrm{SD} 146^{\mathrm{ab}}$ & $308 \pm{\text { SD } 55^{\mathrm{ab}}}$ & $423 \pm \mathrm{SD} 88^{\mathrm{b}}$ \\
\hline Benefit-cost Ratio (BCR) & $1.49: 1$ & $1.7: 1$ & $1.59: 1$ & $1.8: 1$ \\
\hline
\end{tabular}

obtained stocked with 400 and $600 \mathrm{fish} / \mathrm{m}^{3}$ compared with that of $200 \mathrm{fish} / \mathrm{m}^{3}$. The initial average weight of stocked fry was $0.920 .81 \mathrm{~g}$ of $6-8$ weeks age which finally attained $28.65-38.61 \mathrm{~g}$ and fed throughout the experimental period with a diet containing $55 \%$ crude protein.

Specific growth rate deceased as rearing period increased (Figure-2). The final mean body length of all the strains also observed significantly $(p<0.05)$ different among the strains (Table-4). The SGR ( $2.59 \%$ to $2.73 \%$ /day) obtained in this study were comparable with the report of Middendorp [24] for juvenile Oreochromis niloticus in pond culture ranging from $2.2 \%$ to $3.1 \% /$ day. Moreover, the specific growth rate observed in these study was higher than the specific growth rate that reported by other workers [4] obtained for juvenile Oreochromis niloticus. The SGR of Treatment-3 strain found higher $10.08 \%$, which is closed to the SGR $9.75 \%$, $8.89 \%$ and $8.72 \%$ found in Treatment-4, Treatment1 , Treatment-2, respectively.

The best mean values of feed conversion ratio (1.62) was achieved by the Treatment- 4 strain while the poorest mean values of feed conversion ratio (2.44) was achieved by theTreatment-1 strains (Table 4). ranges from 1.62 to 2.44 obtained in this study was consistence with the range of 1.45 to 2.40 for juvenile Oreochromis niloticus in cage culture. Thus, it is possible to say that different strains have different feed conversion ratio at different environmental conditions. In this experiment, Survival of fries, rather than growth, is the key criteria of successful seed production and particularly important in determining the economic viability of advanced nursing or overwintering. All the fries nursed under the same conditions used in the trial for 51 days without any negative effect on survival. Survival in all treatments lies between $70-80 \%$ with highest found in Treatment-2 (80\%) followed by treatment $4(79 \%)$, but there were no significant differences among the treatments.

It is evident from the present experiment that the Treatment- 2 and Treatment- 4 strain showed higher survival than others strain of tilapia. This might be due to genetic variation exists in the strains. The experimental Treatment- 2 and Treatment- 4 strain also a derivative of these better performed strains of tilapia. However, this phenomenon of the better performance might be the cause of genetic variation exists in the strain. 
The results of the present study also showed that fish survival for all stations was reasonably good ranging from $70 \%$ to $80 \%$. This result is in line with the work of Ridha [29] who observed that the survival rate of juvenile Oreochromis niloticus was relatively high for all strains (97.4\% to $100 \%)$ in tank culture. The results of this study also revealed that gross fish yield was affected by strain differences. The maximum gross fish yield was obtained from the Treatment-4 strain $\left(200.13 \mathrm{~g} / \mathrm{m}^{2}\right)$. The lowest gross fish yield was obtained from the Treatment-1 strain $\left(100.04 \mathrm{~g} / \mathrm{m}^{2}\right)$. The Treatment-4 strain had higher gross fish yield than that of the other strain. This result is in agreement with the work of Ridha [29] who found that the strain with the highest growth performance had the highest gross fish yield $\left(45.4 \mathrm{~kg} / \mathrm{m}^{3}\right)$ and the lowest feed conversion ratio (1.27) and the poorest growth performance had the lowest gross fish yield $\left(30.4 \mathrm{~kg} / \mathrm{m}^{3}\right)$ and the highest feed conversion ratio (1.55). The present study though did not deals with stocking densities but to evaluate the four strain of tilapia, same ecological conditions i.e., same environment was maintained where the fry of four strain representing similar size were stocked at a density of $1200 \mathrm{fry} / \mathrm{m}^{3}$ and fed a formulated feed containing protein level of $31.29 \%$ for 51 days. Thus the Breeding Cohort /Treatment-4 strain was proved to be a significantly fast growing fish $(\mathrm{P}<0.05)$. However, much lower final weight attained by both the strains in the present experiment in comparison to that of Cruz and Ridha [12] what could be the effect of sea water cages. Whatever might be the stocking densities in nursery system for tilapia in pond cages in different experiments conducted by some authors, the supplemental feeding ration were as $70 \%$ rice bran and $30 \%$ fish meal at $5-20 \%$ of body weight, $20 \%$ ipil-ipil, $40 \%$ copra meal and $10 \%$ fish meal at $10-20 \%$ of body weight [21]. On the other hand, the feeding ration in the present experiment was quite higher $15-40 \%$ of body weight, as to why the final body weight attainment of fish was comparatively lower to the others.

Recently FRI (Fisheries Research Institute) has developed the techniques of nursing system for tilapia fry. In brief, tilapia fry weighing between 0.5 to $1.0 \mathrm{~g}$ can be stocked in earthen pond at the rate of 25 to 30 individual $/ \mathrm{m}^{3}$ and nursed for 40 to 60 days feeding with a mixture of $50 \%$ rice bran, $40 \%$ mustard oil cake and $10 \%$ dried duckweed (Lemna sp.) at $8-10 \%$ installed twice or thrice daily. The final weight of fry can be attained at 5 to $10 \mathrm{~g}$ within 40 to 60 days. In contrast, the present experiment involved everything alike but in approximation except that of far high density (25 to 30 vs 1200 individual $/ \mathrm{m}$ ) of fry for nursing in pond cages instead of earthen pond. However, the present practice in pond cages though with high density can produce fry weighing between 5 to $14 \mathrm{~g}$ within 51 days. There the attainment of final weight of fry that was within the range of expectation. Therefore, the nursery practice in pond cages can be an efficient way of producing large scale production of tilapia fingerlings.

Different water quality parameters (such as DO, $\mathrm{pH}$, TDS and temperature) measured during the study period and found favourable ranges for rearing tilapia fingerlings (Azaza et al., 2008). However, the temperature ranges from $28^{\circ} \mathrm{C}$ to $30^{\circ} \mathrm{C}$ are optimum for maximum growth of Oreochromis niloticus $[10,16]$. The result obtained in the present study agrees with his observation. The optimum temperature for the growth of Nile tilapia was recorded to range from 20 to $35^{\prime \prime C}$ with an optimum between 28 to $30^{\circ} \mathrm{C}$ [8]. Most tilapia does not eat and grow at water temperature below $15^{\circ} \mathrm{C}[9,13]$. According to Spass [31], the optimum temperature for maximum growth is between 19 to $28^{\circ} \mathrm{C}$. In this study, growth performance of juvenile in terms of the final mean body weight, mean body weight gain and specific growth rate increased gradually and reached to their maximum values at $30^{\circ} \mathrm{C}$ water temperature and decreased at $34^{\circ} \mathrm{C}$ water temperature. These results are in agreement to the earlier works $[17,18]$ who reported that growth performance of juvenile Oreochromis niloticus reared at different water temperature increased as water temperature increased until $30^{\circ} \mathrm{C}$ to $32^{\circ} \mathrm{C}$ and declined when it excided. The present results were also confirmed the earlier works [7] who stated that lower and higher water temperature reduces the growth performance of juvenile Oreochromis niloticus. In case of dissolved oxygen and $\mathrm{pH}$ in the present experiment, the value is acceptable according to Jhingran (1983) and found suitable for fish life which could not have hampered the growth of the fish in the present trial. The total cost that include Hapa cost (Including all cost of net, rope and bamboo $2 \mathrm{~m}^{2}$ hapa cost Tk. 500, it is considered the hapa can be used at least four times with in a season), Tilapia fry (Tk. 0.50 per fry) cost, food cost etc in Treatment-1 is 561, Treatment-2 is 564, Treatment-3 is 525 and Treatment -4 is 527, respectively. At the end of the experiment, highest Total returns (Average Sale value Tk. 2.0 per fry) get from Treatment-2 (957 TK) and Treatment-4 (950 TK) than Rearment-1(834 TK) and Treatment-3 (835 TK).

During financial analysis in this study, local market prices were taken into account to determine the costs and benefits of the selected fish seed production. Investment costs of the fish seed production included: cost of raw materials (net, bamboo, rope, plastic bottle etc.) for hapa and cage construction and placement. The investment costs and return of fish seed production in this study area presented in Table-5.

At the end of the study, the net benefit obtained were $274 \pm$ SD $62^{\mathrm{a}}$ respectively in Treatment-1, $393 \pm$ SD146 ${ }^{\mathrm{ab}}$ respectively in Treatment -2 , $308 \pm{\text { SD } 55^{\mathrm{ab}}}^{\mathrm{b}}$ respectively in Treatment-3 and $423 \pm \mathrm{SD} 88^{\mathrm{b}}$ respectively in Treatment -4. Significantly higher benefit was observed in treatment 4 and lowest in treatment 1 . The benefit- 
cost ratios (BCR) obtained in Treatment-1, Treatment-2, Treatment-3 and Treatment-4 was 1.49 , $1.7,1.59$ and 1.8 respectively.

In summary, Generally, the growth performance of the fry from Breeding Cohort, Sonar Bangla Hatchery, Bamna, Barguna in Treatment-4 strain was ranked first followed by the others strain. The Treatment-1 strain had the lowest growth performance. The results of this study clearly indicated that the Treatment-1 strain had the poorest growth performance among the four strains tested, which is supported by the work of the growth performance of juvenile Oreochromis niloticus strain in Lake Ziway showed the lowest growth performance than found in Lake Chamo and Lake Langano in their natural habitat using otolith analysis.

\section{CONCLUSION}

Bangladesh is considered one of the most suitable countries in the world for dairy farming. The present management condition of small dairy farms in Patiya at Chittagong district is more or less traditional and the productive and reproductive performance of crossbred cows was better than that of indigenous cows. Most of the farmers believe that dairy farming is a profitable enterprise and can be more profitable if Government gives support on feed cost, marketing, loan and management training.

\section{REFERENCES}

1. Abdel-Tawwab M ( 2004). Comparative study of growth performance and feed utilization of four local strains of Nile tilapia, (Oreochromis niloticus L), collected from different location in Egypt. In: Bolivar R., Mair G. and Fitzsimmons, K. (Eds.), The 6th International Symposium on Tilapia in Aquaculture, Manila, Philippines, pp.510-517.

2. Admassu D and Ahlgren I (2000). Growth of juvenile tilapia (Oreochromis niloticus) from Lakes Ziway, Langeno and Chamo (Ethiopian rift valley) based on otolith microincrement analysis, Ecology of Freshwater Fish, 9: 127137.

3. Ahmed M (1956). Transplantaion of food fish to East Pakistan. Pak. J. Sci. 8(4): 167-170.

4. Al-Hafedh YS (1999). Effects of dietary protein on growth and body composition of Nile tilapia, Oreochromis niloticus (L., 1758), Aquaculture Research, 30: 385-393.

5. Anon (1984). Introducing the tilapia. ICLARM Newsletter, 7(1):p.3.

6. Ashagrie $\mathrm{G}$, Getahun $\mathrm{A}$ and Mengistou $\mathrm{S}$ (2008). Effect of stocking density on the growth performance and yield of Nile tilapia [Oreochromis niloticus (L., 1758)] in a cage culture system in Lake Kuriftu, Ethiopia, Aquaculture Research, 39: 1450-1460.
7. Azaza MS, Dhraïef $\mathrm{MN}$ and Kraiem MM (2008). Effects of water temperature on growth and sex ratio of juvenile Nile tilapia, Oreochromis niloticus (Linnaeus) reared in geothermal waters in southern Tunisia, Journal of Thermal Biology, 33: 98105.

8. Balarin JD and Haller (1982). The intensive culture of tilapia in tanks, raceways and cages. In J.F. Muir and R.J. Roberts (eds.), Recent advances in aquaculture. Croom Helm Ltd., 2-10 St. JohnsRoad, London SW 11.

9. Bardach JE, Ryther JH and Melarney WD (1992). Aquaculture: the farming with hasbandry of freshwater and marine organisms. Wiley-lnterscience, New York, London, 868pp.

10. Beamish FWH (1970). Influence of temperature and salinity acclimation on temperature preferenda of the euryhaline fish Tilapia nilotica, Journal of the Fisheries Research Board of Canada, 27: 1209-1214.

11. Bentsen HB, Eknath AE, Palada-De Vera MS, Danting JC, Bolivar HL, Reyes RA, Dionisio EE, Longalong FM, Circa AV, Tayamen MM and Gjerde B (1998). Genetic improvement of farmed tilapias: growth performance in a complete diallel cross experiment with eight strains of Oreochromis niloticus, Aquaculture, 160: 145-173.

12. Cruz EM and Ridha M (1989). Preliminary study on the production of the tilapia, Oreochromt spilurus (Gunther), cultured in seawater cages. Aquaculture and Fisheries Management. 41(2): 216-220.

13. Dendy JS, Varikul V, Sumawidjaja K and Potanos M (1966). Production of Tilapia mossambica (Peters), Plankton and benthos as parameters for evaluating nitrogen in pond fertilizers. FAO Fish. Rep., 44(3): 226-240.

14. Diana JS, Yi Y and Lin CK (2004). Stocking densities and fertilization regimes for Nile tilapia (Oreochromis niloticus) production in ponds with supplemental feeding, In: Bolivar R., Mair G., and Fitzsimmons K.(eds.), The 6th International Symposium on Tilapia in Aquaculture, Manila, Philippines, pp.467-499.

15. Eknath AE, Tayamen MM, Palada-De Vera MS, Danting JC, Reyes RA, Dionisio EE, Capili JB, Bolivar HL, Abella TA, Circa AV, Bentsen HB, Gjerde B, Gjedrem T and Pullin RSV (1993). Genetic improvement of farmed tilapias: the growth performance of eight strains of Oreochromis niloticus tested in different farm environments, Aquaculture, 111: 171-188.

16. El-Sayed AFM (2006). Tilapia culture, CABI Publishing Wallingford Oxfordshire, UK, pp.1-45.

17. El-Sherif MS and El-Feky AMI (2009a). Performance of Nile tilapia(Oreochromis 
niloticus) fingerlings. I. Effect of pH., Int. J. Agric. Biol., 11: 297-300.

18. El-Sherif MS and El-Feky AMI (2009b). Performance of Nile tilapia (Oreochromis niloticus) fingerlings. II. Influence of different water temperatures, Int. J. Agric. Biol., 11: 301-305.

19. Gjedrem T (2005). Status and scope of aquaculture. In: Gjedrem.T. (ed.), Selection and breeding program in aquaculture, Springer, Berlin, New York, pp.1-7.

20. Green BW and Teichert-Coodington DR (2000). Human food safety and environmental assessment of the use of $17 \mu$ methyletestosterone to produce male tilapia in the United States. J.WorldAquacult. Soc., 31:337-357.

21. Guerrero RD (1987). Tilapia farming in the Philippines. Technology and Livelihood Resource Center. Published by National Book Store, Inc., The Philippines.

22. Hapher B and Pruginin Y (1982). Tilapia culture in ponds under controlled conditions. In R.S.V. Pullin and R.H. Lowe-McConnel (eds.). The biology and culture of tilapias. ICLARM Conference Proceedings 7. International Center for Living Aquatic Resources Management, Manila. Philippines, pp.185-203.

23. Maclean JL (1984). Tilapia - the aquatic chicken. ICLARM Newsletter, 7(1): 17.

24. Middendorp AJ (1995). Pond farming of Nile tilapia (Oreochromis niloticus) in northern Cameroon. Feeding combinations of cottonseed cake and brewery waste in fingerling culture, hand-sexed male monosex culture, and mixed culture with police-fish, Clarias gariepinus, Aquaculture Research, 26: 715-722.

25. Palada-De Vera MS and Eknath AE (1993). Predictability of individual growth rates in tilapia, Aquaculture Research, 111: 147-158.

26. Pillay TVR and Kutty MN (2005). Aquaculture principles and practices, UK, Blackwell Publishing, Oxford, pp.400-415.

27. Pullin RSV (1985). Tilapias: "everyman's fish". Biologist, 32(2): 84-88.

28. Rahman AKA (1985). Introduction of exotic fishes in Bangladesh. Paper presented in the seminar on culture of exotic fish in Bangladesh. October 15, 1989. Zool. Soc. Bangladesh. Dhaka University, Dhaka, 14pp.

29. Ridha MT (2006). Comparative study of growth performance of three strains of Nile tilapia, (Oreochromis niloticus L.) at two stocking densities, Aquaculture Research, 37: 172-179.

30. Smith IR and Pullin RSV (1984). Tilapia production booms in the Philippines. ICLARM Newsletter, 7(1): 7-9.

31. Spass J.T., 1960. Contribution a la biologic de quelques cichlides, IN. Phenomeies energiques on funection de la temperature. Hydrobiol., 14 : 155-176.

32. Steehu G., 1962. Freshwater fishes of the world vista Books, London. 